\title{
THE LIONS OF LESOIT: SHIFTING FRAMES OF PARAKUYO MAASAI INDIGENEITY
}

\section{Kelly Askew and Rie Odgaard}

\section{Battling Lions}

As dusk fell on April 10 ${ }^{\text {th }}, 2012$, an unlucky cow in the village of Lesoit, on the Maasai Steppe of central Tanzania, met its death in the jaws of a lion. ${ }^{1}$ This was the seventh cow (plus one donkey) to meet this fate-a rash of killings that began in March the previous year. Located at some distance from the national parks where prides of lions wander freely, suffering little but boredom and incessant gawking from tourists, Lesoit had not faced lion attacks in some seventeen years. Over the course of the year that these killings occurred, a deepening existential crisis beset this Parakuyo Maasai community, for if there are two things that Maasai are famous for, it is protecting their cattle and killing lions.

Parakuyo tradition holds that when a lion attacks, a series of traps are set near the carcass and a lion blind (a shelter for concealing hunters) is dug out in the earth, expertly camouflaged by branches, packed soil and logs. Three-not two, not four-warriors (ilmurran) occupy the

\footnotetext{
${ }^{1}$ Research in Lesoit village, Kiteto District, Manyara Region was undertaken by an international and interdisciplinary team of scholars from May 2010 to July 2012 funded by the National Science Foundation (NSF). Team members: K. Askew, R. Odgaard, F. Maganga, H. Stein, L. Nyeme, E. Sulle, K. Owens, V. Makota, C. Ndomba, S. Gerald, R. Mangilima. In May 2011, with funding from the Mellon Foundation, K. Askew, F. Maganga and L. Nyeme returned to Lesoit with two filmmakers P. Biella and I. Drufovka at village chairman F. Kaipai's request. The participation of all and funding from NSF and Mellon is gratefully acknowledged.
} 
blind (oltapit) for as many nights as necessary until the lion is killed or has clearly moved on with no intent of return. Lions are known to hunt in the early evening, so with each of these attacks, oltapit were duly constructed and Lesoit's brave ilmurran argued over who would be given the privilege of occupying it to await the lion's return. And yet, attack after attack, the ilmurran remained empty-handed.

After the sixth cow had been lost, Lesoit's leaders deemed that a cultural intervention was necessary. They decided to organise exuberant celebrations called Eng'ilakinot that honor lion-killers following a successful kill, overlooking the fact that the lion had yet to be killed. They hoped that by honoring lion-killers still alive in the community, it would inspire the ilmurran that they, too, could attain such fame and honor. But this celebration would include a pedagogical component not found in a typical eng'ilakinot. Village leaders approached a famed lion-killer named Kunando Nyorei and asked him to oversee the building of two mock oltapit by the ilmurran that would be subjected to his supervision and critique. They decided, moreover, that the ilmurran would prepare themselves just as they normally would in advance of a lion hunt by eating only meat roasted in a secluded camp (orlpul) and by consuming traditional medicines that confer bravery and remove all fear (kiloriti and muktan). They would then occupy the blinds and face Kunando's criticism of the construction of their blinds, their stance and conduct within them, the placement of their weapons, placement of their bait and their endurance.

These changes to tradition met no resistance from Lesoit elders. They, too, worried that their warriors had somehow lost the knack of lion killing. And some feared that their culture was in arrears due to increasing numbers of Lesoit warriors migrating to Zanzibar to earn cash working as night watchmen and for the chance to land a 
European girlfriend. Meiu (2009) has described a related phenomenon of Samburu pastoralists from northern Kenya traveling to the coastal city of Mombasa to find European girlfriends and the material advantages such relationships confer. He writes, "In the 1980s... women from European countries (but also, to a lesser extent, from Australia, North America and Japan) began visiting Kenya armed with a clear image of the tall, slim bodies of the 'vanishing' Maasai morans (warriors), walking half-naked, covered only by their red shukas (body blankets) and proudly carrying their spears and clubs. In the early 1990s, Kenya emerged as yet another international sexual destination... its draw relied intensively on eroticised representations of the Maasai and Samburu" (Meiu 2009, 109). By far the most commercialised instance of this is the memoir Die weisse Massai ("The White Maasai”) by Corinne Hofmann (1998), a Swiss-German woman who on holiday in Mombasa found herself intensely attracted to a Samburu moran whom she married, had a child by, and ultimately left. It was made into a major motion picture in 2005 and spawned two sequels and a spot on the American show 60 Minutes. $^{2}$

Currently in the village of Lesoit, with an adult male population of around 450, there are at least eight men that have ongoing, long-term, foreign girlfriends or wives and countless others who have had such relationships in the past, thanks to labor migration to Zanzibar. While eight may not sound significant, any interracial relationship in a rural Tanzanian village is remarkable, much less eight times over. Such transnational couplings draw significant attention. And, they often provide new sources of income, in addition to an exotic romance that inversely complements the desires and expectations discussed by Partridge (2012) of German women in their relationships with African

\footnotetext{
2 Transcript available at:

http://sixtyminutes.ninemsn.com.au/stories/tarabrown/259465/meet-the-whitemasai.
} 
students and immigrants: an opportunity to travel and experience another culture while staying at home in Germany.

The area surrounding Lesoit bears witness to an earlier interracial relationship. Visit long enough and someone may point out to you the "Maasai Mzungu" ("European Maasai"), a man in his early forties born of an early cross cultural entanglement between a Maasai woman and a European man. ${ }^{3}$ You'll then likely be told in a triumphant tone of how he rejected his father's offer to move to Europe in favor of choosing his Maasai identity and remaining in the village to live a Maasai existence.

This essay explores some of the ways in which Parakuyu, a minority group among the Maa-speaking communities of East Africa known collectively as 'Maasai', perform Parakuyo indigeneity through cultural practices, narrative, song, poetry, and ritual. Not intended as a detailed analysis of Parakuyo cultural traditions, rather, our purpose is to examine how one Parakuyo community deploys their traditions as tools for confronting contemporary challenges, readily modifying them as needed. Marginalised both in respect to other Maasai communities and to the broader nation-state, and subject to endless incursions on their land by outsiders, this community is struggling to attain the promises of modernity while maintaining their distinctive sense of self. Not bound blindly to tradition, as some would have it, Parakuyu constantly innovate and develop new strategies for pursuing their economic, political and social goals. Thus, in contrast to popular depictions of culture as an obstacle to development, what we describe

\footnotetext{
${ }^{3}$ There are varying stories circulating about this man's history. Some say his father was a priest. Others say he was Turkish and involved in the ivory trade. The common thread of something illicit-a noncelibate priest or trade in a banned item-is worth noting. It may serve as a coded metaphor for the social stigma accompanying interracial relationships in early postcolonial (1960s) Tanzania.
} 
here is how this indigenous community actively taps their reservoir of tradition in their pursuit of development. Yet, their proud insistence on being identified as pastoralists with origins from distant places inadvertently, we argue, contributes to their economic and political marginalisation.

\section{Performing a Pedagogical Eng'ilakinot}

The same pride with which the story of the Maasai Mzungu is told was evident in abundance on June $1^{\text {st }}, 2011$ when Lesoit held its somewhat unconventional eng'ilakinot celebration. Earlier that year, the village chairman had approached one of the authors and asked if she could help them document an upcoming special event on film, as it was to be one that they wanted future generations to be able to see. Arrangements were duly undertaken and a small film crew arrived three weeks early to learn as much as they could before attempting to film what was described as a 'lion festival' (tamasha la simba in Kiswahili). ${ }^{4}$

Three days before the main event, and under the supervision of their age-grade leader and spokesman (a warrior assigned responsibility for (1) acquiring expertise from elders on all cultural matters pertaining to warriorhood, and (2) representing the warriors in village discussions), the warriors started digging their mock lion blind (oltapit). Two days later, they constructed a second oltapit in a different style: a more temporary-and considerably more dangerous-blind constructed of branches and leaves. Anyone occupying such a blind faces great risk given that branches and leaves offer scarce protection from the strength of an attacking lion. Still,

\footnotetext{
${ }^{4}$ The Chairman and the Lions, directed by Peter Biella and produced by Kelly Askew, an official selection of the 31st Jean Rouch International Film Festival, November 2012.
} 
knowledge of how to quickly and skillfully erect such a blind in cases where a lion attacks late in the day (thus not allowing time for the digging of a subterranean oltapit) is valued knowledge. And, the fact that lions typically return to continue feeding from their kill presents an opportunity no warrior would want to miss.

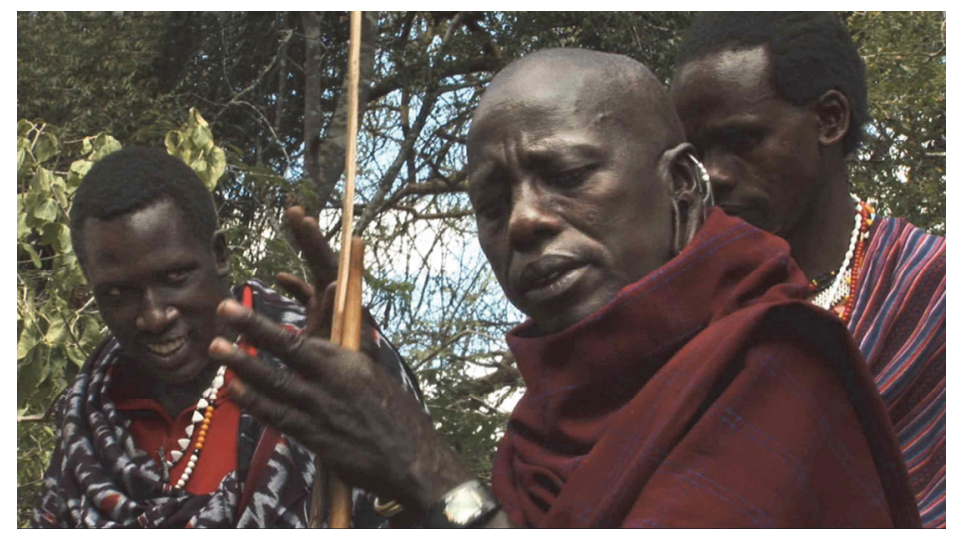

Photo 1 Lion-killer Kunando Nyorei offering comments with village chairman Frank Kaipai (left) looking on

On June $1^{\text {st }}$, famed lion-killer Kunando Nyorei gathered with a small group of elders to judge the efforts of the warriors and their enactment of how they would behave when occupying an oltapit. First, Kunando evaluated the underground oltapit, an impressively unobtrusive lump in the landscape that housed three armed warriors, each with his weapon pointed at a different piece of imaginary bait set out in three spots (to the right, to the left and in front of the opening to the oltapit). After Kunando was satisfied that they had assumed and sustained correct positions and evinced the desired single-mindedness of purpose required of a successful lion-killer whose eyes must never stray from his assigned piece of bait, he indicated that they could exit the oltapit. As they climbed out, one warrior was chastised for wearing 
sunglasses, which he removed with haste: "You went in there with your sunglasses! What's wrong with you?" asked an elder. "Did you come here to look beautiful? Take those glasses off!"

The second oltapit appeared to an unknowing eye to be but a bush. A tall bush, perhaps, but a bush nonetheless. Yet upon close inspection, one could identify the tip of an arrow, the point of a spear, and the barrel of a rifle protruding from the leafy branches, again with each aimed in a different direction. Kunando and the elders commenced discussion of the merits of this "emergency" oltapit and the dangers of occupying it. Other warriors were gathered nearby to watch the evaluation of their comrades and to listen to what Kunando had to say. One now hesitantly asked if use of a flashlight was allowed at night. Vehemently, Kunando replied:

"Absolutely not! You cannot turn on a flashlight because if you are in a blind you cannot even swallow your own saliva because if you swallow the lion will hear it. And if you scratch yourself, the lion will hear it. So if you are inside this you must be like the dead. There is even a special way of breathing... There's no talking or shifting position. You must be still like a corpse until you kill the lion.”

Now in the case of an actual lion kill, the first warrior to deal the lion a fatal blow (be it with spear, arrow or rifle, the latter being a slightly less admirable weapon) is honored as a hero and affixes to his spear the trophy of the lion's tail to publicise his feat of courage. Since warriors typically hunt in a group, the warrior who delivered the second fatal blow attaches part of the lion's left paw to his spear, indexing his secondary hero status. Going into this enactment of hunting procedure, the warriors had selected from among their ranks two warriors whom they decided best exemplified the ideals of concentration, determination, bravery and endurance. Lacking lion parts to signify their selection as the festival's heroes, both were 
anointed with red ochre and the warrior selected to be the primary hero was adorned with a special headdress that framed his face with black and white colobus fur (aesthetically recalling the mane of a lion). The secondary hero was given an iron leg bell tied just above his right knee, and both he and the second hero were directed to pose for our cameras with colorful shields that had been specially commissioned for this eng'ilakinot featuring a painted lion and the phrase "Maasai Lesoit Village."

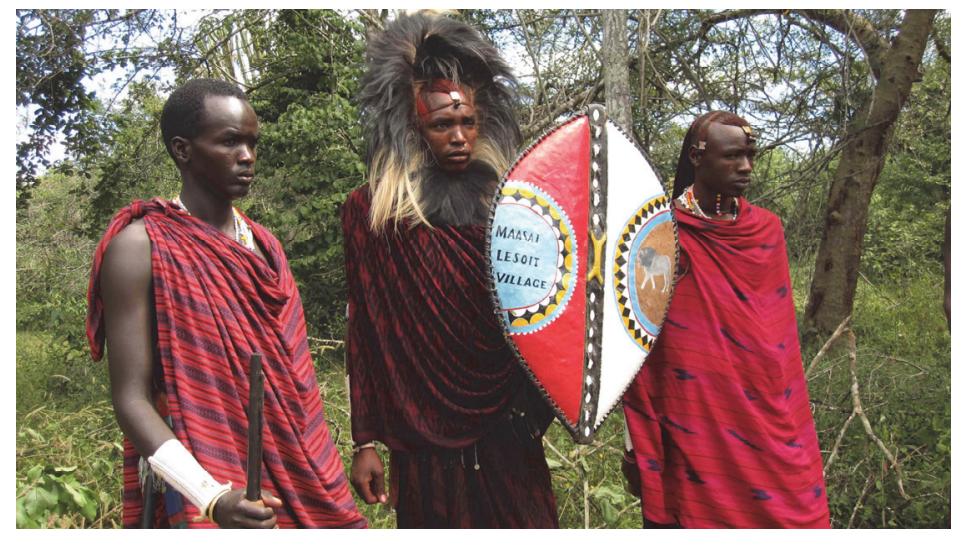

Photo 2 Primary hero with black and white colobus headdress and shield. Photo credit: K. Askew

With the oltapit evaluations complete, the warriors disappeared. To ensure that people would turn out in large numbers to complete the celebratory component of this performed eng'ilakinot, but also to maximise expenditures, the village leaders opted to pair it with an actual celebratory event. A ritual called olorbak binds two men who 


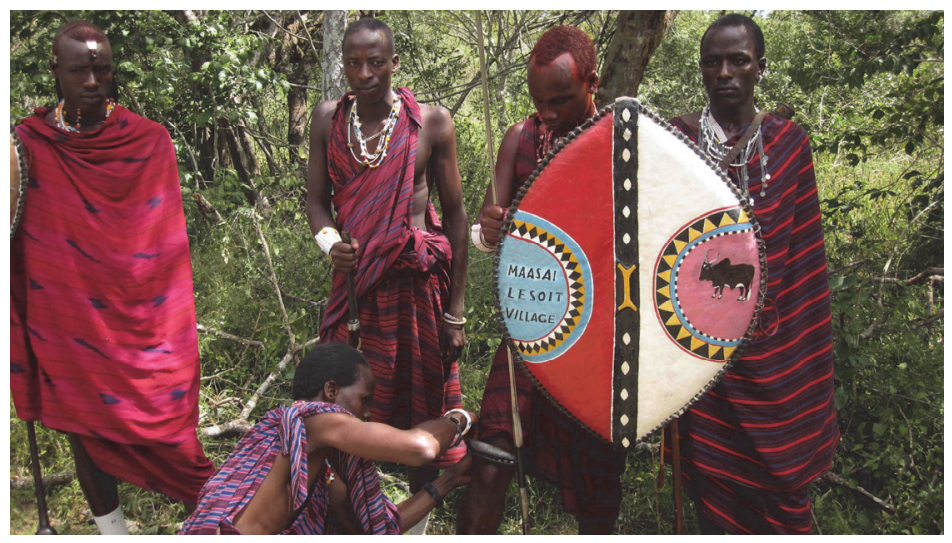

Photo 3 Secondary hero with bell being attached to his leg by fellow warrior. Photo credit: K. Askew

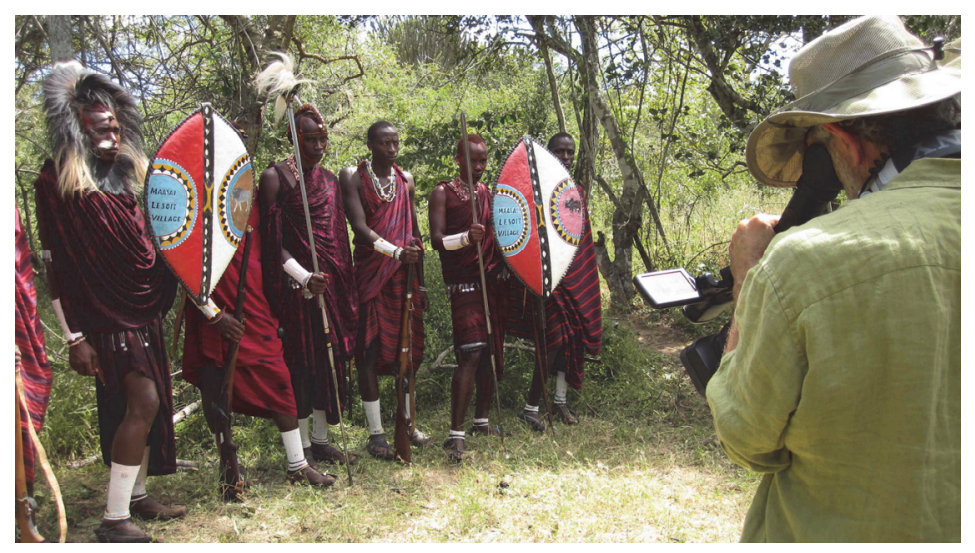

Photo 4 Posing for director Peter Biella's camera. Photo credit: K. Askew

have "retired" from warrior status as blood brothers for life. It also reunites the warriors from their cohort, who come to witness this ritual, and sing, feast and reminisce about their warrior days late into the night and throughout the following day. Feasting, dancing, and singing also characterise eng'ilakinot festivities. Thus, song served as 
the transition linking the two celebrations. Silently processing singlefile towards the celebration site, the warriors reappeared with the primary hero leading the procession. At punctuated intervals, other warriors would in turn suddenly exit the line to run ahead and shout out formulaic texts honoring their ties to the land, their deep knowledge of the land and lions, and their bravery:

My father, my father

I wasn't late but the trip was long

Serai! Serai! Serai! ${ }^{5}$

I wasn't late to arrive at my Serai grasslands

It's only that the trip is long

I wasn't late

The lion cannot deceive me there in my grassland

Where the warriors make camp and eat meat

Serai! Serai! Serai!

Serai my father is a narrow river

Praise my arm that bears this heavy shield!

Praise my arm that bears this heavy shield!

My father, I wasn't late but the trip was long

My father, I call upon you when I am as fierce as fire

My father, I wasn't late but the trip was long

My father! My father! My father!

Serai! Serai!

My Serai grassland, your warriors are as fierce as fire!

Mtambalo valley with the narrow stream

Serai, where the lion dances with its flowing mane

Mtambalo! Kibaya!

My Serai grassland, your warriors are as fierce as fire!

Lion, you cannot deceive me there.

Serai! Serai! Serai!

\footnotetext{
${ }^{5}$ Serai is the name of an area near Lesoit teeming with wildlife.
} 
The warriors processed until they reached the cattle kraal, which they entered to form a large semi-circle. Three warriors overcome by emotion and the effects of the afore-mentioned traditional medicines consumed in large quantities to stave off fear and enhance ferocity, entered a trance and lunged headfirst into the thorn enclosures walling the kraal. They had to be extracted and handled gently by fellow warriors until they returned to consciousness. Had one veered toward judging this eng'ilakinot 'inauthentic' due to lack of a dead lion, the actions of these warriors would have dispelled it. Their immunity to puncture wounds, their extreme agitation and their unnatural strength (each requiring three warriors to successfully restrain them) exposed altered states of being. Performativity replaced performance. The other warriors, however, acted as though nothing were amiss and continued to process solemnly into the center of the kraal, until their horseshoe formation was complete and the singing could commence.

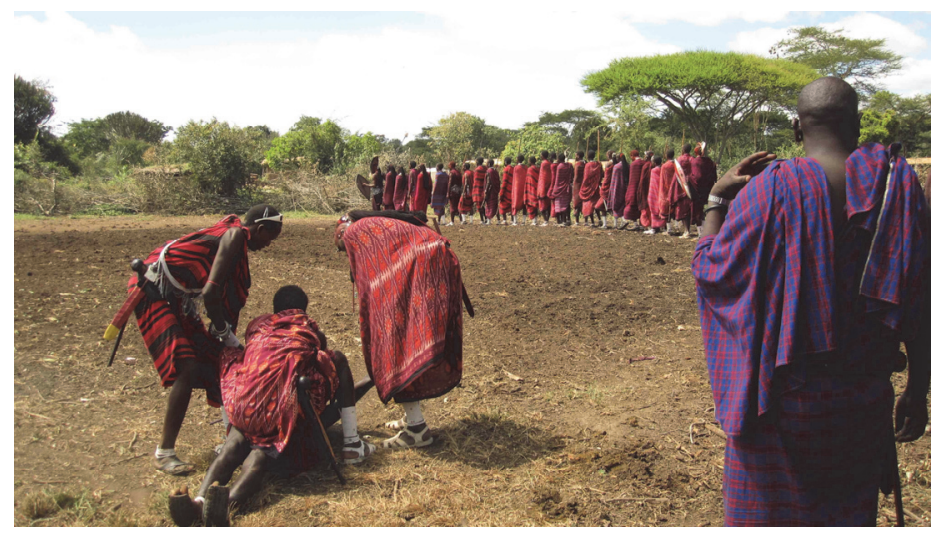

Photo 5 Warriors preparing to sing with collapsed warrior restrained by others in foreground. Photo credit: K. Askew 
In normal circumstances, such a formation would have immediately drawn a counter formation of young girls who would dance opposite from and sing in counterpoint to the warriors. This being a pedagogical eng'ilakinot, however, the maidens didn't appear until the olorbak festivities kicked in later on. Instead the warriors sang a series of three songs, all of them having to do with protecting cattle and hunting lions. One was entitled Emburkoi:

Eepi iyok iremeta nejulo tolonyoke kimbokie Olesiria opi ingiri olng'atuny

Simanjiro aii nakinya kimbokie olouwaru engaina enanga

Ipuko ilouwarak tengorongoro neyok nado ilong'oi naipukie
Our weapons are sharp and have mixed with the blood of the lion. The hero from Olesiria clan battled many lions.

On our Simanjiro grasslands we stopped the lion by distracting it with our robes.

The lion ran away from Ngorongoro because of our heroes with their red shields. Yes, it ran away.

In the red ravine, Olentaparri showed off his heroism in battle by sounding his leg bells.
Olentaparri tolodo murrutot kidaraki tolndwalan ingitung'ati ejore

With their special repertoire of songs about bravery and the need to outwit their adversaries, whether lions or cattle rustlers, the ilmurran exuberantly performed their youthful vigor. They leapt high into the air, individually taking turns to rush suddenly into the middle of the circle towards onlookers, where young maidens rather than a film crew would ordinarily be. Some would leap solo, others would swing long braids about in a whirl of motion. And, underlying the songs, 
sounded a guttural ostinato chant -part human, part lionacoustically uniting warriors with their foe.

These trajectories, of traditions undergoing intentional modification and of transnational yearnings, represent some of the realities of contemporary Parakuyo communities. These communities certainly vary greatly in their performance of indigeneity to foreigners, to the state, to neighboring communities and to themselves. In Zanzibar, migrant warriors perform a version of Maasai-ness carefully designed to appeal to tourists, especially those of the female sex. ${ }^{6}$ Yet in this remote corner of the former colonial Maasai Reserve, away from the gaze of tourists and government officials, this one Parakuyo community proudly performed their Parakuyo-ness, their modified eng'ilakinot, for themselves, their neighbors, and an invited film crew. And, in doing so, they also affirmed their identity as pastoralists (in singing of defeating lions that attack their cattle), their identity as Maasai (proudly proclaimed on their commissioned shields), and their ties to, and deep knowledge of, their land (via the poetic texts identifying elements of the landscape known to the community and valued especially by the warriors). This cultural intervention served its intended purpose. One year and eight victimised livestock later, the ilmurran succeeded in killing their lion.

\section{Parakuyo/Maasai Indigeneity}

Parakuyo communities are marginalised several times over. They are numerically disadvantaged relative to the dominant Kisongo Maasai, who live in and around the tourist centers of Arusha, Ngorongoro, and Nairobi. Perhaps the most dominant section (iloshon) of the

\footnotetext{
${ }^{6}$ For a comparable Kenyan case, see Bruner and Kirshenblatt-Gimblett 1994.
} 
Maasai complex, ${ }^{7}$ the Kisongo in the late $19^{\text {th }}$ century waged war against the Parakuyo in the famed Iloikop Wars (Beidelman 1960; Berntsen 1979; Galaty 1993; Jennings 2005a, 2005b; Waller 1978; Weatherby 1967) and nearly succeeded in eradicating Parakuyo altogether. Kisongo is the section of Maasai that, historically, has had better access to education and been able to attract international funding. They therefore have received greater attention globally, both as featured exotica in Nike, American Express, high fashion and mobile phone advertising campaigns, as well as in international political forums aimed at protecting the rights of indigenous peoples. They are identifiable visually through their highly colorful beadwork (as opposed to the Parakuyo preference for mostly white beadwork), different styles of head ornamentation, and the cloths preferred by women: aurally through dialectical differences, and spatially through their contiguous territorial homeland spanning northern Tanzania and southern Kenya.

It was a Kisongo Maasai, Moringe ole Parkipuny, who, in 1989, first attended the United Nations Working Group on Indigenous Populations (see Hodgson 2009, 2011; Dahl 2012) to lay claim for an African presence in that august entity. Through Maasai mobilisation efforts and the support of some international associations, ${ }^{8}$ the United Nations Working Group for Indigenous Populations (UNWGIP) belatedly accepted African communities (Maasai, Pygmy, San, Berbers, Amazigh and others) within their mandate. In this

\footnotetext{
7 There is no scholarly or Maasai agreement on how many sections of Maaspeaking peoples there are, but the most commonly cited are: Kisongo, Siringet, Salei, Purko, Matapato, Loitai, Laitayiok, Kaputiei, Uasin-Kishu, Siria, Raal, Samburu, Arusha and Parakuyo. See Kipury 1983; Spear and Waller 1993. ${ }^{8}$ Most significantly the Denmark-based International Working Group for Indigenous Affairs (IWGIA).
} 


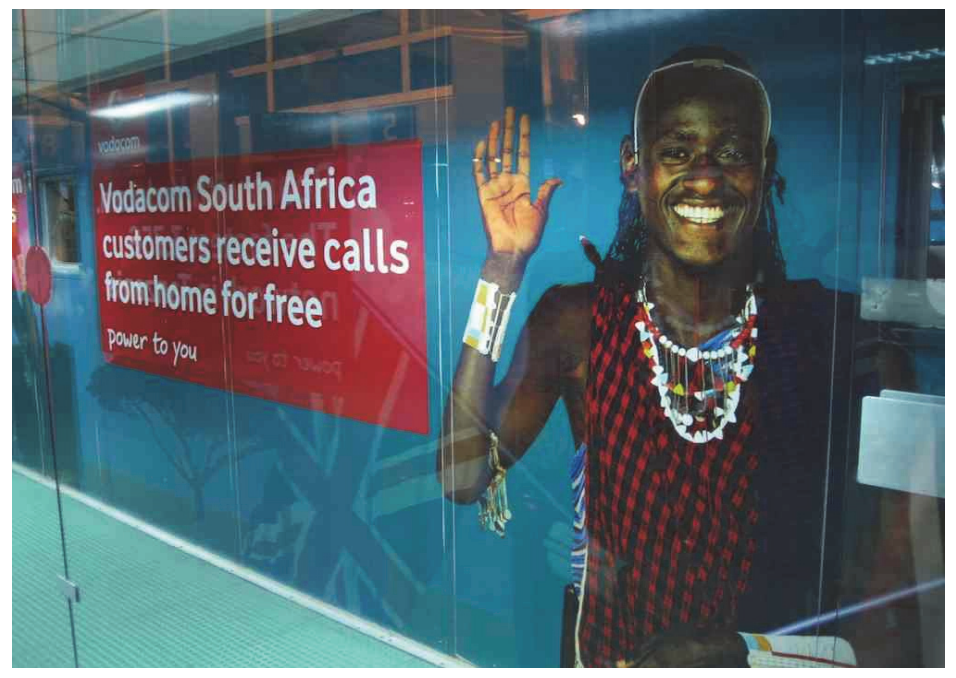

Photo 6 Mobile telephone advertisement one sees upon arrival in the Dares Salaam airport. Photo credit K. Askew

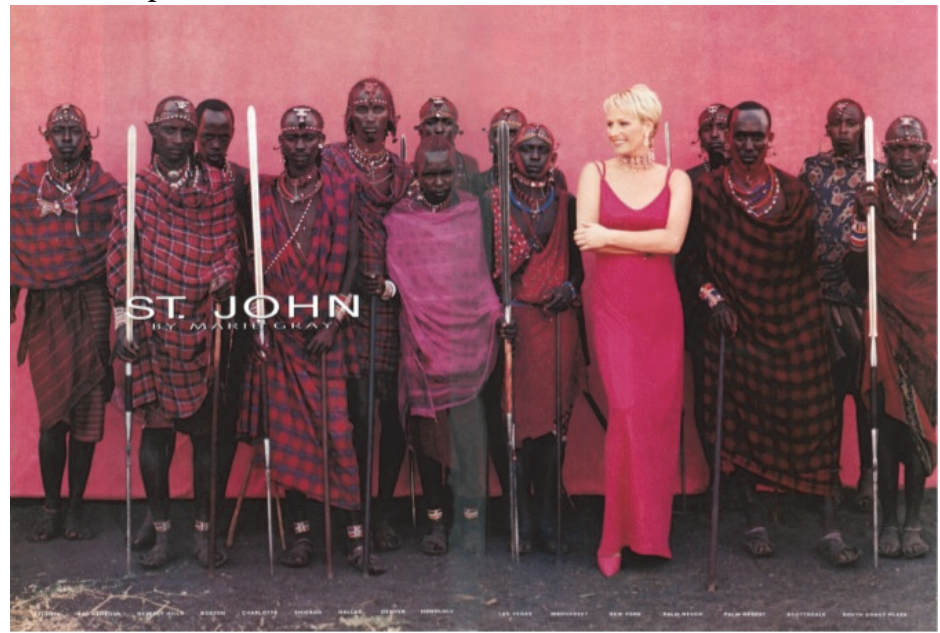

Photo 7 Fashion designer advertisement 


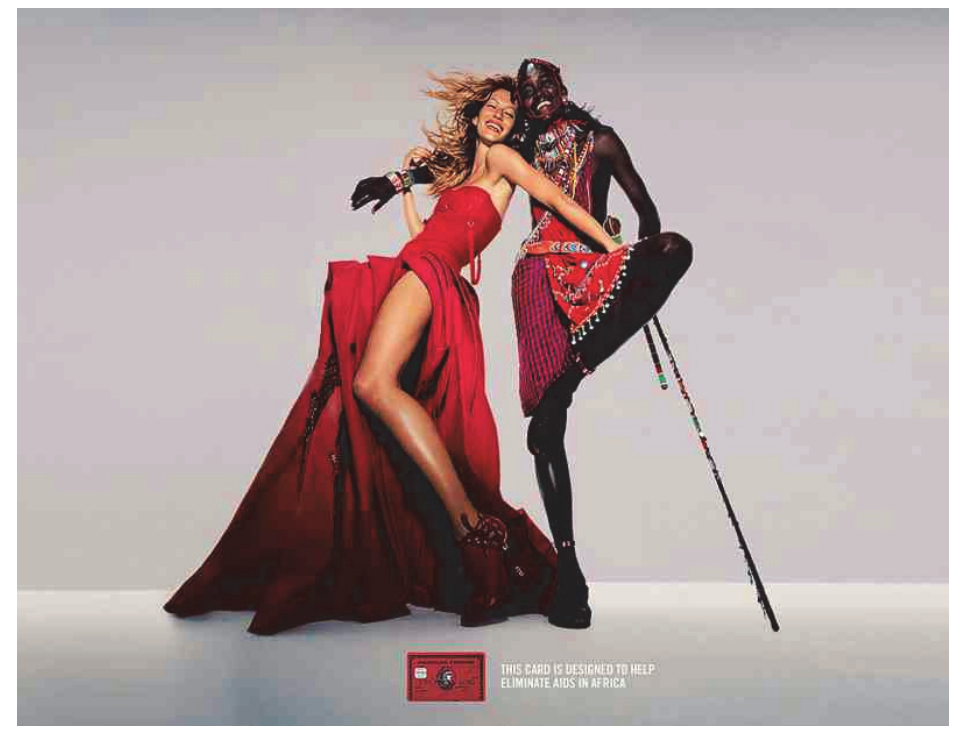

Photo 8 American Express advertisement featuring an eroticised white female-Maasai warrior relationship

context, "indigenous" is defined not in terms of place of origin (Maasai being no more or less "indigenous" to Africa than, say, Yoruba or Luo people) but by the vulnerability and marginal position of their way of life in the face of state policies of neglect or outright oppression. Thus, in international arenas, "indigenous" populations are those who "struggle for rights being denied them" (Dahl 2012, 189), and in East Africa, it is pastoralist (e.g., Maasai, Barabaig, Turkana, Rendille, Samburu) and hunter-gatherer groups (e.g., Akie, Sandawe, Hadzabe, Borani, Okiek) who self-identify as such.

Despite there being many sections of Maasai, Maasai are frequently reduced to Kisongo-ness. Indeed, some scholars even refer to Parakuyo as being outside the Maasai complex, granting Parakuyo (or 
'Kwavi' or 'Humba,' both derogatory terms applied to Parakuyo) separate ethnic status even though they share a common languageMaa-and common dependence on pastoralism with the other Maasai sections. Beidelman, for instance, noted:

Much of the confusion in the various historical sources and in Government reports dealing with Masai and related groups lies in the indiscriminate application of the terms 'Masai' and 'Kwavi' to any Masai-type people. Usually 'Masai' is reserved for those who appear to fill the classic Masai stereotype of the observer and 'Kwavi' is applied to those people who do not quite fit this stereotype but who speak languages similar to Masai, such as Arusha, Meru, Baraguyu, Taveta, Njemps, etc. Often 'Kwavi' merely refers to any Masai-like group observed tilling land. (Beidelman 1960, 246, cited in Maganga et al 2007)

Parakuyo today are dispersed over a wide geographic span stretching from coastal Tanzania (Tanga, Bagamoyo, Kilwa) across the central plain (Morogoro, Kiteto) to the Southern Highlands (Iringa, Mbeya), leading one scholar to call them the "Scatterlings of East Africa" (Jennings 2005a). This is due in part to the conflicts with the Kisongo and in part to their active search for ever-shrinking grazing land and greater economic opportunities. And, like all pastoralist and huntergather communities, they suffer the disdain of the majority of Bantu farmers (who view their claims to land as suspect), and they suffer open discrimination from the national government. Recent statistics indicate that Tanzanian pastoralists currently number around 1.5 million (in a total Tanzanian population of around 40 million) and contribute at least $30 \%$ of the agricultural GDP, producing some $90 \%$ of meat and milk products (de Jode and Hesse 2011: 9). Yet, despite making critical contributions to national economic growth, pastoralists in Tanzania are consistently discriminated against and denied basic human rights. 
Pastoralism as a way of life is popularly viewed as incompatible with modern development goals and in need of eradication. Indeed, the current president of Tanzania, Jakaya Mrisho Kikwete, in his opening speech to Parliament on December 30, 2005, insisted:

Mr. Speaker, we must modernise animal husbandry. We will have no alternative. We must abandon altogether nomadic pastoralism which makes the whole country pastureland.... The cattle are boney and the pastoralists are skeletons. We cannot move forward with this type of pastoralism in the twenty first century (cited in ole Ndaskoi 2009, 3).

It is a sentiment one finds echoed in other mass-mediated formats, such as newspaper editorials:

Why does it seem that livestock keepers never do something, anything, to minimise their losses through drought and, instead, practically sit on their hands, watching their herds die off as a matter of course? I mean, for example, why do they not sell them off when the going is still good? (The Citizen, 14 September 2011).

One scholar, an advocate for pastoralist rights, argues that government officials:

fail to see a vibrant system of livelihood that supports an energetic and vibrant population of Tanzanians. A system that at minimal cost provides stable sources of animal protein to the majority of Tanzanians that ranching, with all its sophisticated paraphernalia, has failed to deliver (Tenga 2011, 19).

In recent decades, laying claim to "indigenous" status has offered marginalised communities, like African pastoralists and huntergatherers, routes to international alliances, collective strategies and financial support to combat their victimisation at home. Indigeneity- 
impossible to define and always contested-tends to be affiliated with the following characteristics:

The indicators, of which some but not necessarily all will be present at any time, are self-identification, historical continuity as a people, firstcomers, aboriginality, territorial connection with a region, distinct identity, marginalisation and discrimination, non-dominance, distinct culture and language, and being in a minority position. A few indicators could be seen as essential, such as self-identification, a wish to retain a specific identity, connection to a specific region, and a history of being dominated through eviction, assimilation, marginalisation, genocide or other forms of suppression or colonisation. Indigenousness seems further to be inevitably linked to the formation of modern states, which is part of the explanation why indigenousness acquired its global significance following the independence of former colonial territories in Asia and Africa and the collapse of the Soviet Union... (Dahl 2012, 190-91).

Parakuyo proudly self-identify as Parakuyo Maasai and as pastoralists, and they mark their distinctiveness through their dress and dialectic. But they do not tell histories of being first-comers. On the contrary, more often than not, they tell a highly formulaic narrative common to many if not all Maasai communities of being originally from the Levant, migrating over centuries to northern Africa, continuing in a southerly direction until reaching the area of what is now Nairobi, Kenya, where the sections (iloshon) parted ways to establish their respective territories. Parakuyo explain their lack of any identifiable territory through their near-genocide by the Kisongo, which caused them to be dispersed far and wide. The narratives they tell may be a contributing factor to their political persecution, for although archaeologists, linguists, and historians tell us that Bantu cultivators similarly traveled to East Africa from a point of origin in West Africa in the 'Bantu Expansion,' you will not often hear farming 
communities refer to themselves as being immigrants to the areas in which they now reside (Odgaard 2005; Maganga et al. 2007).

No more "indigenous" to central Tanzania than Maasai, Bantu cultivators nevertheless claim longstanding land rights as tillers of the soil, marking the earth with their crops, their graves and their permanent dwellings-all visible evidence of human occupation. Pastoralists, however, traverse the landscape leaving few traces of their engagement with the land. Until recently, they did not bury their dead. Until recently, they constructed temporary structures, easily dismantled or simply abandoned when the household would move in search of better pasture or water. Thus, the reiterated narrative one finds in Maasai communities of being originally from a vaguely but proudly identified elsewhere, while perhaps an attempt at reclaiming distinctiveness in the face of political marginalisation, inadvertently contributes to their marginalisation by offering neighboring farming communities fodder for denying the legitimacy of their claims to land and to equal representation in politics. Moreover, the connotation of foreignness that they encourage allows government officials to frequently evict them on grounds of being non-citizens, of being Maasai from Kenya who wandered over the border illegally, a claim difficult to refute since many Maasai lack official identification like passports or identity cards or birth certificates. ${ }^{9}$ One doesn't hear

\footnotetext{
${ }^{9}$ In response to a proposed government bill requiring livestock keepers to register and obtain ID tags for every animal they own, MP Benedict ole Nangoro argued that "the bills had not taken into consideration the fact that pastoralists were still using traditional methods to tend their animals... 'Pastoralists have no time to take their children to clinics or obtain birth certificates for them. How can they possibly take their cattle for registration?' he asked." "“Government withdraws livestock bills," The Citizen 04/15/2010.
} 
similar accusations lodged against the other ethnic groups (e.g., Luo, Kuria, Digo) similarly divided by the colonial borders and living in different nation states (see for example Coulson 1982).

Indigeneity is a frame of discourse that has recently come to be embraced by Maasai, as discussed at length by Hodgson $(2009,2011)$ and Dahl (2012). One need only consider the number of NGOs focused on pastoralist issues in Tanzania with the term embedded within, such as the Parakuiyo Pastoralists Indigenous Community Development Organization (PAICODEO) and the Pastoral Indigenous NGOs Forum (PINGOs). Unpopular with their government for claiming this status, which implies they precede other groups in the area, Maasai employ different self-labels as situations demand. For as Dahl argues, indigeneity proves to be less about prior settlement or authenticity than about vulnerability and rights denied.

'Indigenous peoples' is not an anthropological idea, nor is it only a modern term for earlier ideas of 'tribes', 'primitive people', or 'natives' as Beteille (1998) seems to indicate but a term used by an increasing number of peoples who themselves have been united by specific historical and global circumstances and conditions [that] precisely like all other social phenomena have trajectories in relationship with other peoples, movements or the creation of new political units such as the state (Dahl 2012, 190).

\section{Competing Discourses about Parakuyo Identity}

According to one common narrative, Parakuyo Maasai are more tradition-bound than the more dominant Kisongo Maasai due to their marginalisation within the greater Maasai complex and because so very few Parakuyo have attained any education beyond primary school. The dispersal of Parakuyo in minority enclaves across multiple regions of Tanzania has resulted in their being left out of many 
development initiatives. Pastoralist-oriented programs typically benefit Kisongo for ease of access. And given the correspondence between the Kisongo homeland and the most popular tourist destinations (e.g., Ngorongoo, Serengeti), the ensuing economic advantages have enabled considerable numbers of Kisongo to pursue advanced education. Thus it is not uncommon to find Kisongo professionals in the fields of law, politics, medicine, and education thanks to boarding schools in and around Arusha town for Maasai children, who are almost always Kisongo.

A second, competing narrative casts Parakuyo (along with Arusha Maasai) as being less-than-fully Maasai not on account of their military defeat but for being agro-pastoralists: communities that combine pastoralism with a heavy dose of agriculture. A Maasaicentric perspective would hold that only unsuccessful pastoralists would choose this option, but the realities of cattle disease, drought and decreasing access to grazing land made the choice one of economic necessity a long time ago, not only for Parakuyo and Arusha Maasai but also for Kisongo and other Maasai subsections. Archaeologists tell us pure pastoralism never existed, since the historical record is replete with evidence of trade between pastoralist communities and farmers. Yet, one consequence for many Parakuyo following the wars with the Kisongo was out-migration from the Maasai heartland to areas where they could find pastures for their livestock and to some extent land for cultivation. In 1962, Beidelman noted that "the Baraguyu are perhaps the most dispersed people in East Africa" and that they had been so for well over a hundred years (Beidelman, 1962, 8).

This second perspective thus holds that Parakuyo are innovators (as illustrated by the Lesoit example above), who are willing to experiment and not bound to an orthodox tradition. It thus reorders 
Kisongo-Parakuyo comparisons, with the Kisongo emerging (especially in tourist brochures and travel guide books) as the more traditional, more pure Maasai. Another strand of Parakuyo innovation concerns the theme introduced previously of sexual relationships. Odgaard has noted that Parakuyo men in Iringa and Mbeya regions often marry women from farming communities, for example from the Gogo, Bena and Sangu ethnic groups, who are more engaged in agricultural activities than the Parakuyo. ${ }^{10}$ While highly uncommon for a first (and thus most senior wife) to be anything but Parakuyo, a man's second or third wife might come from one of these communities, thus bringing agricultural knowledge and increased agricultural success into the family. One can see marriage and romance, then, as a strategy for diversifying household income that predates-by several generations - the recent migrations of Parakuyo warriors to Zanzibar and 'Mombasa Morans' in search of cash and the possibility of a European lover.

Whether Parakuyo or Kisongo can lay greater claim to 'Maasai-ness' or pastoralism as a way of life is a moot question. Both communities engage in a combination of pastoralism and agriculture, though interestingly both communities typically 'farm out' the labor of farming to those who do it best: farmers, either by marrying them or hiring them as day laborers. ${ }^{11}$ Both communities have retained a strong sense of being Maasai, and when faced with a common threat from invading farmers seeking to steal their land, they forge alliances and join forces against those whom they collectively refer to as olmeek, non-pastoralists (literally, "the uncircumcised ones"). And, both combine a passion for tradition with openness to innovation in equal

\footnotetext{
${ }^{10}$ A number of such examples were observed by Odgaard during fieldwork in Usangu Plains in 1985, 1990 and 1991.

${ }^{11}$ Yet, in the case of Lesoit, no one could identify a mixed Parakuyo-Bantu marriage.
} 
measure. What is of interest to us here, however, is how discursive assessments of traditionalism or innovation are used to further marginalise Parakuyo communities and further enhance the reputation of Kisongo. Whichever label gets applied to Parakuyo communities, it is applied in a negative fashion: they are either traditional to the point of being backward, or innovative to the point of no longer being true Maasai.

\section{Lesoit: A Minority Enclave}

During the 1970s, socialist-era efforts to both consolidate power and provide social services to the populace resulted in the moving of over 10 million people-some freely, most forcibly -into villages (vijiji) composed of at least 250 households. Operation Vijiji affected the vast majority of Tanzanians. Yet, there were communities that managed to duck its effects, namely those not dependent on a sedentary existence: hunter-gatherers and pastoralists. However, by the 1990s, the national government developed a sophisticated toolkit for dealing with these communities who, as noted above, were viewed with suspicion and derided publicly for not supporting the goals of modernisation. Hence, more and more hunter-gatherer and pastoralist communities have decided that adopting sedentarism, at least for official recordkeeping purposes, will tame some of the $21^{\text {st }}$ century lions that they now battle: low levels of education, inadequate access to healthcare, and continual, increasingly violent, strife with farming communities whose claims on land slowly but surely are cutting off the pastoral corridors they have been travelling seasonally for centuries.

Thus it was in 1992, two decades after most of Tanzania's 11,000 villages had been established, that 250 households of Parakuyo Maasai formally registered a new village with Kiteto District officials. One of only a handful of fully Parakuyo Maasai villages scattered across 
Tanzania, ${ }^{12}$ this community named their village 'Lesoit' for the natural granite reservoir in the village center. The 15,600 hectares that became Lesoit village was taken from the adjoining village of Lengatei, a village dominated by immigrant Nguu farmers who moved to the area in the 1970s answering the government's call to establish villages and attracted by the soil fertility of the Maasai Steppe. The steppe, by virtue of having been a "native reserve" set aside exclusively for Maasai pastoralists under British colonialism, had never been cultivated, and thus is today the site of much land grabbing and conflict.

So, to their south and to their east, Lesoit villagers are surrounded by farmers who view the land that to unknowing eyes looks unused with envy. Compared to the tidy rows of maize or beans that characterise the 8,700 hectares remaining in the densely populated Lengatei, the beautiful, large and untamed miombo woodlands of Lesoit-kept precisely that way for purposes of grazing cattle, goats and sheeplooks, if not unused, then underused. Lesoit's elected and appointed leaders are frequent visitors to nearby courts, answering to or lodging lawsuits against invading Lengatei farmers. ${ }^{13}$

To the north and west lie the Kisongo Maasai villages of Loolera, Lembapuli, Olkitikiti and Engang'uengare, all of which engage in agricultural activities to the same extent or even more as the Parakuyo of Lesoit. Kisongo-Parakuyo cleavages remain most evident in

\footnotetext{
${ }^{12}$ According to interviews with Adam ole Mwarabu, coordinator of the Parakuiyo Indigenous Community Development Organization (PAICODEO), and Frank Kaipai, chairman of Lesoit village, there are only 22 majority Parakuyo villages in the country. Interview with authors, May 10 and May 23, 2012, respectively. ${ }^{13}$ We analyse two such cases in "Of Land and Legitimacy: A Tale of Two Lawsuits," forthcoming in Africa: Journal of the International African Institute, vol.. 28, no. 4, February 2013.
} 
marriage decisions, with few cross-subsection marriages occurring, and in their respective ritual schedules, with the initiation of new agegrade cohorts following different calendars. Nevertheless, they have come to each other's assistance in times of need, even waging together a violent if brief war against invading farmers from Nkama village in neighboring Kilindi District who sought to lay claim to an area of Lesoit with a natural water source shared by Lesoit and Loolera. That conflict, the Mtambalo conflict of 1998 (Mtambalo being one of the significant landmarks praised in the warrior's poem above), affirmed the worldview that these pastoralists share whatever their differences: their mutual commitment to living a life based largely, even if not exclusively, on pastoralism.

\section{Culture for Development and the Development of Culture}

One last example will serve to illustrate how Parakuyo of Lesoit are employing their cultural traditions to develop their community, in the process developing-or as described to us "improving and strengthening"-their cultural traditions. ${ }^{14}$ A problem that emerged recently in Lesoit (a problem that afflicts many communities in the country) is alcoholism. The community has a number of alcoholics who are slowly but surely selling off their cattle to support their drinking habits. Facing the prospect of having all the wives and children of these men reduced to relying on the village to support them, in 2002 the village leaders convened a meeting of their male elders and traditional experts. A long debate as to what to do and how to address the situation ensued, in which each member of the meeting spoke and offered an opinion. Although Parakuyo, like other Maasai communities, generally recognise male heads of households as owners

\footnotetext{
${ }^{14}$ The authors thank Jens Dahl for his contribution of the contrast between developing culture and culture for development.
} 
of the household cattle, the ultimate decision was to strip four men of their ownership rights to their cattle and instead recognise their wives as the legitimate owners of the household wealth.

This radical decision constituted a community-initiated (if maledominated) effort to prevent further erosion of the economic well being of these households and forestall their otherwise imminent impoverishment. Had they been reduced to destitution, these households would have likely been the beneficiaries of another Maasai tradition of holding a community cattle collection to help restore some wealth to these households. So, in this case, the alteration of cultural practice helped the community avoid collections for four families, which would have been highly unpopular and a heavy burden on the village. Taking the unusual step of recognising women as household heads-in these cases women who were not widowed, divorced or single-is a significant break from Maasai tradition. But, as all who spoke with us about it insisted, it was for the betterment of the community as well as these families.

Quite some time later, one of the authors happened to be telling the Kisongo manager of an NGO focusing on Maasai development about this breach of tradition. He was most impressed to hear about Lesoit's cultural intervention. He expressed surprise but then wished aloud that his Kisongo community would follow Parakuyo's lead and take similar steps in dealing with their problems with alcoholism.

\section{Conclusion}

The proudly Parakuyo Maasai of Lesoit face multiple threats from within and beyond their communities: predatory lions that stalk their cattle, cultivators that encroach on their land, government officials that undermine their rights to a pastoralist existence, inadequate 
access to education and healthcare, alcoholism, and gender discrimination. These are struggles common to Maasai and other pastoralist, as well as hunter-gatherer, communities throughout Tanzania and Kenya. They are also struggles common to indigenous communities throughout the world-struggles to avoid having their livelihoods fundamentally altered and their land forever alienated. The international indigenous rights movement has helped frame these demands for cultural self-determination within a rhetoric of human rights: that it is a basic human right to pursue a livelihood that has defined a community as a community for a long period of time. And, over the past two decades, Maasai have availed themselves of international fora, such as the United Nations, to lay claim to these rights while also continuing to agitate for equality at the national and local level.

Outside of such highly public venues, away from the attention of the media and state bureaucrats, Maasai are developing their own internal responses to the threats they face. The stories here from Lesoit show how a community under duress can draw strength from its traditions and simultaneously strengthen these same traditions to better serve collective needs. But here, as in most cultures, contradictions can be found. The pan-Maasai autohistorical narrative of foreign origins offers land-starved neighbors a weapon to use in challenging their rights of residence, even as their music and poetry shares intimate knowledge of the landscape, its features, and their placement within it. The warriors' pride in being Maasai and the guardians of a globally admired set of traditions masks the not atypical strategy of marrying or romancing women who happen to have desirable economic attributes, be it skill in agriculture or access to foreign exchange. And, at root lies the paradox that Maasai performative insistence on being members of an internationally recognised indigenous group through dress, language, and adherence to cultural practice contributes to their 
deepening marginalisation in a profoundly modernist and antipastoralist atmosphere.

The discrimination and violent advances that Maasai face from their governments and neighbors require them to be ever alert, ever vigilant, and to draw strength from their shared sense of self and communal reservoir of cultural practice. By performing that shared sense of self, making it manifest through celebrations after (or on rare occasion, before) killing a lion, through appearances in global venues defending the rights of indigenous peoples, or in local courts to thwart illegal incursions on their land, and through a military front when all other modes of negotiation fail, Parakuyo and Kisongo Maasai take indigeneity out of the realm of discourse and international politics and convert it into a tangible resource deployed in the battle for full legal and social recognition in Tanzania.

\section{References}

Beidelman, T. O.'A demographic map of the Baraguyu,' Tanganyika Notes and Records, 58 and 59 (1962): 8-10.

Beidelman, T. O. "The Baraguyu," Tanganyika Notes and Records, 55 (1960): 245-78.

Berntsen, J. L. 'The enemy is us: eponymy in the historiography of the Maasai.' History in Africa 7 (1979): 1-21.

Bruner, E. and B. Kirshenblatt-Gimblett. 'Maasai on the lawn: tourist realism in East Africa.' Cultural Anthropology 9, 4 (1994): 435-470.

Coulson, A. Tanzania: A Political Economy. Oxford: Clarendon Press, 1982.

Dahl, J. The Indigenous Space and Marginalized Peoples in the United Nations. Basingstoke: Palgrave Macmillan, 2012. 
De Jode, H. and C. Hesse. Strengthening Voices: How Pastoralist Communities and Local Government Are Shaping Strategies for Adaptive Environmental Management and Poverty Reduction in Tanzania's Drylands. Tanzania: IIED, KDSC and TNRF, 2011.

Galaty, J. 'The eye that wants a person, where it can not see?' Inclusion, exclusion and boundary shifters in Maasai identity.' In Being Maasai: Ethnicity and Identity in East Africa, edited by T. Spear and R. Waller, 174-193, Oxford: James Currey, 1993.

Being Maasai, Becoming Indigenous: Postcolonial Politics in a Neoliberal World. Bloomington: Indiana University Press, 2011.

Hodgson, D. 'Becoming indigenous in Africa,' African Studies Review 52, 3 (2009): 1-32.

Jennings, C. C. 'Scatterlings of East Africa: revisions of Parakuyo identity and history, c.1830-1926.' Ph.D. thesis, University of Texas, Austin, 2005a.

Jennings, C. C. 'Beyond eponymy: the evidence for Loikop as an ethnonym in nineteenth-century East Africa.' African Studies Review 32 (2005b): 199-220.

Kipury, N. Oral Literature of the Maasai. Nairobi: Heinemann Educational Books, 1983.

Maganga, F. P., Odgaard, R. and E. Sjaastad. 2007. 'Contested identities and resource conflicts in Morogoro Region, Tanzania: who is indigenous?' In Conflicts over Land and Water in Africa, edited by B. Derman, R. Odgaard and E. Sjaastad, 202-214. Oxford: James Currey, 2007.

Meiu, G. P. 'Mombasa morans': embodiment, sexual morality, and Samburu men in Kenya,' Canadian Journal of African Studies/La Revue canadienne des etudes africaines 43, 1 (2009): 105-128. 
Ndagala, D. K.. 'The Ilparakuyo livestock keepers of Bagamoyo: persistent fighters but ultimate losers.' Working Papers in African Studies No. 32. University of Uppsala, 1986.

Odgaard, R. 'The struggle for land rights in the context of multiple normative orders in Tanzania.' In Competing Jurisdictions. Settling Land Claims in Africa, edited by S. Ewers, M. Spierenburg and H, 243-264. Leiden: Brill Publishers, 2005.

Ole Ndaskoi, N. Pastoralism on the Horns of a Dilemma: A Report of Consultancy Commissioned by PINGOs-Forum. Pastoralist Indigenous Non Governmental Forum, 2009.

Partridge, D. Hypersexuality and Headscarves: Race, Sex and Citizenship in the New Germany. Bloomington: Indiana University Press, 2012.

Spear, T. and R. Waller. Being Maasai: Ethnicity and Identity in East Africa. London: James Currey, 1992.

Tenga, R. 2011. 'Seeking redress from courts of law by pastoralists in Tanzania.' Paper presented to the conference on Half a Century Struggles by Pastoralists for Land Rights: Examining Achievements, Challenges and the Proposed New Constitution as a Window of Opportunity, organised by ALAPA \& PINGOs Forum, Arusha, 24-25 November 2011.

Waller, Richard. 1978. 'The lords of East Africa: the Maasai in the $19^{\text {th }}$ century (c.1840-c.1885).' Ph.D. dissertation, Cambridge University.

Weatherby, J. M. 1967. 'Nineteenth century wars in Western Kenya,' Azania 2 (1), pp.133-144. 